\title{
Conversion of byproduct carbon obtained from spent pot liner treatment plant of aluminum industries to blast furnace tap hole $\operatorname{mass}[18]$
}

\author{
B. Mazumder, Sasmita Rani Devi \\ Institute of Minerals \& Materials Technology, Bhubaneswar, Orissa, India
}

\begin{abstract}
The paper describes a method for converting carbon powder obtained as byproduct while decontaminating spent pot liner by acid treatment route, into blast furnace tap hole mass. Producing an useful industrial product from waste helps in paying back the cost incurred during decontamination process of spent pot liner and thus improves the overall economics of the process.

Keywords: Waste utilization, recovered carbon utilization, blast furnace tap hole mass, spent pot liner.
\end{abstract}

\section{Introduction}

Blast furnace tap hole mass is a prepared muddy material used to close the tap hole of iron making blast furnace. At iron melting temperature the material carbonizes and becomes hard in order to hold the metallostatic pressure inside blast furnace hearth. Since iron gets oxidized at high temperature this tap hole compound is prepared predominantly from carbonaceous material. Further these carbonaceous materials used needs to be semicrystalline in nature in order to withstand high temperature of the furnace. With rising cost of such carbonaceous material used in tap hole compound, it will be advantageous if a source of cheap carbon material matching the properties of carbon material already in use in the tap hole recipe, could be found in order to bring down cost of production of commercial taphole recipe. The aim of this research was to find such a carbonaceous material from an industrial waste which is difficult to dispose because of its toxic contaminants. Such a material chosen for this work is called SPENT POT LINER of aluminum smelter plant.

At present majority of the aluminum smelter plants round the world use Hall-Heraoult's electrolysis process for extracting aluminum metal from molten cryolite. The electrolysis cell used for this purpose constitute large carbon blocks as cathode laid at the bottom and side wall of the cell. These carbon electrodes are known as pot liners and basically made of anthracite, graphite and binder/electrode pitch. Various manufactures uses $20-30 \%$ [1] graphite in their recipe in order to meet electrical properties needed for the pot liner. While graphite is a superior electrical conductor than anthracite (which has similar structure to graphite), $100 \%$ graphite is never used in the manufacture of pot liners as it is soft and can not withstand turbulent molten cryolite contained in the cell. Anthracite on the other hand provides required mechanical property to the finished pot liner. The prefabricated pot liner produces carbon matrix with short range order. Thus prepared pot liners ultimately contain both crystalline (graphite) and amorphous carbon.

During service molten cryolite slowly gets reduced and the sodium fluoride crystal deposits within the fine crevices of pot liner creating defect spots. As time passes, these crystals grow and exert pressure within these crevices resulting in the propagation of crack. As a consequence, with time the pot liner looses its electrical property and ultimately being discarded. These rejected waste pot liners are called "spent pot liners" (in short SPL). Spent pot liners are not only contaminated by fluoride but also by other toxic elements such as cyanides (formed at high temperature reaction with atmospheric nitrogen), alkalis and aluminum. Table-1 below shows typical range of the contaminants in such discarded pot liners along with concentration of these toxic elements in SPL carbon powder after decontamination with oxidizing acids.

In practice suitability of a specific component in a commercial recipe is tested by evaluating some gross property of the modified recipe against the production recipe of the compound. For example, in development of foundry chemicals (like mould coating, tundish cover, hot tops etc) which basically a combination of various components in a formulation, various substitutes are being tried with above procedure of gross evaluation of certain properties of the compound in order to determine its suitability. Similarly in present case of developing suitable substitute of carbonaceous material in commercial tap hole compound recipe, following properties are important in order to determine its suitability.

Apparent porosity. This property determines the ease with which gas generated in the tap hole compound during carbonization can escape easily without breaking or decreasing strength of the carbonized tap hole mass. This value is generally maintained in the range $25-35 \%$.

a) Bulk density. This is maintained in the range $1.3-1.6 \mathrm{gm} / \mathrm{cc}$ in all commercial recipe in order to match with standard pushing length required by the equipment to fill the tap hole. 
b) Permanent Linear Shrinkage. This value is restricted within the narrow range of $0-2.5 \%$ in order to guarantee adhesion of the tap hole compound to brick lining and also not to crumple during carbonization.

c) Cold crushing strength. This value is maintained over a broad range of $40-160 \mathrm{~kg} / \mathrm{cm}^{2}$ in order to allow the carbonized tap hole compound withstand metallostatic pressure in the furnace while it is soft enough to be drilled out after the campaign is over by standard equipments.

Table- 1: Typical contaminants in SPL and their concentration after chemical treatment with oxidizing acids.

\begin{tabular}{|c|c|}
\hline Contaminants in untreated SPL & Contaminants in treated SPL \\
\hline Fluoride - 6-9\% & Fluoride $140-170 \mathrm{ppm}$ \\
\hline Aluminum - 1-2\% & Aluminum 10-15 ppm \\
\hline Cyanide - 0.2-0.4\% & Cyanide $\quad 0.1$ to $0.2 \mathrm{ppm}$ \\
\hline Alkali - 7-9\% & $0.5-0.7 \%$ \\
\hline
\end{tabular}

Because of the presence of these toxic elements in large quantities, disposal of spent pot liners in open field poses great environmental risk. Moreover, generation of these spent pot liners by aluminum smelter plants on regular basis being very high (NALCO, Angul itself produces 450 tones spent pot liners per month on the averages) safe disposal of such huge quantity of toxic waste material have been a long standing problem with all aluminum smelters round the world. Efforts have been made to decontaminant these SPL by hydrothermal treatment with partial success as only $45 \%$ of the contaminants gets washed out by this process. Concentrated alkalis while leaches away most of the contaminants, extent of removal of the contaminants is very low and can not be translated into actual plant practices. Accordingly majority of smelters at present adopts a policy to crush these spent pot liners to fine powder and burn them in a PF-burner. While this process destroys contaminants in the SPL, it emits pollutant gases such as fluorides and not acceptable by present plant practices. As mentioned earlier, preparation of pot liners comprises use of special carbons and recovery of these valuable carbons in terms of its real commercial value outweighs many times than realizing its calorific value alone. Spent pot liner on the other hand can be decontaminated by treatment with various strong oxidizing acids [2-7]. IMMT, Bhubaneswar, India scaled up such a wet process which extracts all the contaminants in SPL in liquid phase and simultaneously recovers its carbon value as a byproduct. Accordingly the process while decontaminates SPL, generates byproduct carbon powder which can be used to make a number of important industrial carbon products [8-18]. Attempts have also been made to utilize the spent pot liner in producing cement from spent pot liner [19]. In such case the spent pot liner is used as a fuel supplement as well as mineralizing agent in cement kiln. In present experiments the SPL derived carbon powder was used to prepare blast furnace tap hole mass an important industrial product which consumes large volume of semicrystalline carbon. Another reason to find possible use of SPL carbon powder in above product was relative cost of the carbon powder obtained as byproduct from SPL treatment plant. Till now no such attempts have been taken to utilize SPL derived carbon powder as full or partial replacement of carbon in blast furnace tap hole recipe. The properties which are essential in developing a blast furnace tap hole compound are:

a) Flow smoothly when pushed by the clay gun to plug the tap hole.

b) cure within the tap hole during the plug to tap time but without shrinkage to ensure a tight seal

c) be drilled in an acceptable time

d) allow a stable controlled melt stream tap without spray

e) withstand erosion by iron and slag

f) form a stable substrate for next plug

g) Provide a stable and controlled tap hole length. Modern blast furnace work with a tap hole length of 2-3.5 meters.

h) Should be sufficiently porous after curing in order to allow resultant gases to escape easily.

Accordingly commercial tap hole mass is produced from a mixture of refractory materials including carbon powder bonded by tar or synthetic organic binder Carbon powder used in the production of blast furnace tap hole compounds by various commercial manufacturers generally ranges from $10-35 \%$. In order to be able to withstand high temperature of the blast furnace as well as to be oxidation resistant, semicrystalline carbon and sometime carbides are used for this purpose. Compositions of some tap hole compounds made by various commercial manufactures are show in table-2 below. 
Table-2: Composition of some commercial tap hole clays

\begin{tabular}{|c|c|}
\hline Name of the company & ipproximate composition of blast furnace tap hole mass \\
\hline \multicolumn{2}{|c|}{ Saint-Gobain Ceramic: UK } \\
\hline & Silicon carbide + carbon $=40 \%$ \\
\hline & Silica + Crude Silicon $=15 \%$ \\
\hline & Alumina $($ Bauxite $)=29 \%$ \\
\hline & Binder $=16 \%$ \\
\hline \multicolumn{2}{|l|}{ Nippon Crucubles: } \\
\hline & Refractory aggregates $=60-85 \%$ \\
\hline & Graphite + Silicon Carbide $=5-30 \mathrm{gm}$ \\
\hline & Clay $=5-15 \mathrm{gm}$ \\
\hline & Binder $=15-25 \mathrm{gm}$ \\
\hline & Organic fiber $=0.01-0.75 \mathrm{gm}$ \\
\hline \multicolumn{2}{|c|}{ Riverside refractories (plant of CHZONOW) } \\
\hline & Silica $=65 \%($ Grain size $=0-3 \mathrm{~mm})$ \\
\hline & Density $=2.2 \mathrm{gm} / \mathrm{cc}$ \\
\hline & Total carbon $=20 \%$ \\
\hline & Alumina $=10 \%$ \\
\hline & Loss of ignition $=10-20 \%$ \\
\hline \multicolumn{2}{|c|}{ Cherepovetsk plant (Russia)(Vanchikov, 1065) } \\
\hline & Clay $=16.7 \%$ \\
\hline & Ground coke $=50 \%$ \\
\hline & Coal tar pitch $=16.7 \%$ \\
\hline & Grog powder $=16.6 \%$ \\
\hline \multicolumn{2}{|c|}{ ACC Refractories (Mumbai), India } \\
\hline & Alumina $=7.5 \%$ \\
\hline & Silica $=90 \%$ \\
\hline & Iron oxide $=0.8 \%$ \\
\hline & Titanium oxide $=0.5 \%$ \\
\hline & Graphite powder $=2 \%$ \\
\hline
\end{tabular}

Attempts were made in present experiments to replace the conventional carbon content in tap hole mass recipe with the byproduct carbon powder obtained from SPL treatment plant as mentioned above. The incentive for such replacement comes from the relatively low cost and abundant supply of carbon powder from SPL treatment plant. The other advantage is that sell of these byproduct carbon to other industries will pay back fully or partially the cost incurred in decontaminating SPL in the above treatment plant.

\section{Experimental}

The spent pot liner derived carbon powder was first characterized through studies involving scanning electron microscopy, differential thermal analysis, $\mathrm{x}$-ray diffraction and ash determination. While ash was found to vary between $5-10 \%$ (for handpicked first cut SPL), alumina in ash found to vary $20-52 \%$ and silica $42-72 \%$, while loss on ignition (LOI) was $1-2 \%$.

Experiments were designed to study possible application of SPL derived carbon powder in making blast furnace tap hole mass using two separate recipes containing 23\% and 26\% of SPL derived carbon powder. Suitability of a particular blast furnace tap hole recipe is evaluated by certain standard tests both at room temperature and after curing the compound at high temperature. These properties include apparent porosity, bulk density, permanent linear shrinkage, and cold crushing strength.

Liquid resin binders such as Resol and Novolac are used for preparing the blast furnace tap hole compounds. In this case they were prepared as follows:

Resol : $50 \mathrm{gm}$ phenol is added to $60 \mathrm{ml}$ formalin and $1.06 \mathrm{gm} \mathrm{NaOH}$. The mixture was stirred for about 15 minutes to make it homogeneous and then heated at constant temperature $\left(80-90^{\circ} \mathrm{C}\right)$ till the gas bubbles comes out the heating mixture. The mixture was cooled for 5-10 minutes at room temperature and then stored in an air tight bottle in a freezer.

Novolac : This resin was prepared by adding $50 \mathrm{gm}$ phenol to $32 \mathrm{ml}$ formalin and $5 \mathrm{ml}$ hydrochloric acid (commercial grade). The mixture was stirred for about 15 minutes to make it homogeneous and then 
heated to constant temperature of $80-90^{\circ} \mathrm{C}$ and hold at this temperature until bubbles starts coming out. It was then cooled for 5-10 minutes at room temperature and then kept in refrigerators until use.

Commercial binders thus prepared do not contain stabilizer and added to the tap hole clay as soon as it is prepared.

Other solids components such as refractories, used in the recipe were prepared as follows. Refractory raw materials such as alumina, silica, silicon carbide, titania, ferric oxide etc were first dried at $120^{\circ} \mathrm{C}$ for 2 hour in an oven and sieved through -100 BS mesh. The dried and sieve mixture was then put into a Muller mixture into which liquid ingredient (like binder) were added with constant stirring. This process continued for about 20 minutes to make a homogeneous clay. Viscosity of the resultant clay was simultaneously fixed by the ratio of liquid to solid mixture in the Muller mixture.

Property of the tap hole mass after high temperature curing was measured first by compacting $100 \mathrm{gm}$ of above clay in an Universal Tensile Machine using steel die and applying a force of $200 \mathrm{~kg} / \mathrm{cm}^{2}$. The compact thus prepared was put into a steel cylinder and packed with coke and then fired at about $1000^{\circ} \mathrm{C}$ for 2 hours in ambient (atmospheric) pressure of the furnace. The drillabilty, apparent porosity, bulk density, permanent linear shrinkage, and cold crushing strength were determined in order to adjudge its suitability for application as blast furnace tap hole compound

\section{Result and discussion:}

Properties of the SPL derived carbon powder as measured in our laboratory, is shown in Table 3 below. X-ray diffraction analysis of the SPL derived carbon powder is shown in Figure-1 while results of Scanning Electron Micrograph is shown in Figure-2 below. Results of differential thermal analysis with above carbon powder is shown in Figure-3. Figure-1 clearly shows that the carbon powder derived from SPL is crystalline in nature because of its clear cut peaks but not as sharp as natural flaky graphite. Thus the carbon powder obtained from SPL treatment is semicrystalline in nature. Crystallinity of the SPL derived carbon powder is further confirmed from Figure-2 which shows clearly disposition of geometrically shaped crystals under scanning electron micrography. Thermal behavior of such powder is exemplified in Figure-3 which compares its rapid oxidation temperature around $600{ }^{\circ} \mathrm{C}$ when compared to natural graphite. This high temperature sustainability towards oxidation makes it's a suitable candidate for application in the tap hole compound recipe.

Table -4 shows the values obtained for above mentioned properties of blast furnace tap hole compositions containing 24\% SPL derived carbon powder (composition 1), while Table-5 shows the same results obtained with composition-2 containing $32 \%$ SPL carbon powder.

X-ray diffraction and Scanning Electron Micrography results as mentioned above for SPL derived carbon powder, indicates that these carbon powders are semicrystalline in nature and could be a possible good candidate for use in blast furnace tap hole mass recipe. Semicrystalline nature of carbon powder imparts thermal stability to the carbon powder. Differential thermal analysis when compared with graphite powder indicates high oxidation resistance of the SPL carbon powder at high temperature. These results thus points to possible use of the carbon powder in blast furnace tap hole recipe.

After preparation of the two recipes (composition -1 and composition -2) and curing them at high temperature, properties which are necessary for blast furnace tap hole compound, as mentioned above, were evaluated. Table 4 and 5 shows these results and Table- 6 shows the same properties generally found with some commercial tap hole compounds. Comparison of these two tables indicates that SPL derived carbon powder can be used successfully in producing blast furnace tap hole compounds upto at least $30 \%$ replacement level. Increasing SPL carbon content further decreases apparent porosity and increases permanent linear shrinkage beyond acceptable limit. Further increasing SPL carbon content in the recipe calls for increase in resin content to maintain desired cold crushing strength and drillability but at the same time permanent linear shrinkage and apparent porosity goes beyond acceptable limit.

Accordingly it is concluded that carbon powder derived from SPL treatment can be used to replace conventional carbon in commercial blast furnace tap hole mass compositions.

Table 3: Properties of SPL derived carbon powder.

\begin{tabular}{ll} 
Fixed carbon & $80 \%$ and above (Protocol: IS 3150) \\
\hline Ash content & $6-10 \%$ (Protocol: IS 3150) \\
\hline Moisture & $1.2 \%$ average (Protocol: IS 3150) \\
\hline Bulk density & $525.5 \mathrm{gm} /$ lit (Protocol: IS 877/1989) \\
\hline Iodine number & $920 \mathrm{mg} / \mathrm{gm}$ (Protocol: ASTM D1510) \\
\hline Methylene blue & 155 \\
\hline Particle size distribution & $0-3 \mathrm{~mm}$ (plant discharge)
\end{tabular}




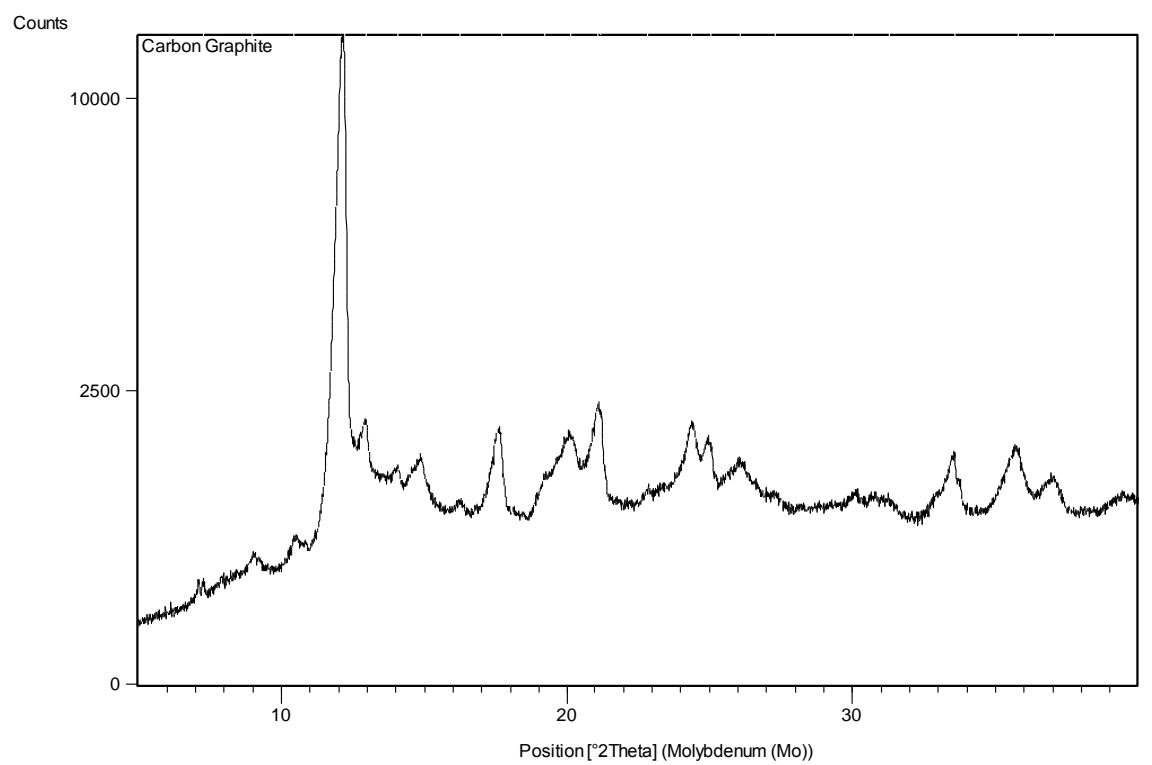

Figure 1: X-ray diffraction of SPL derived carbon powder

Peak list:

\begin{tabular}{|c|c|c|c|c|}
\hline Pos. [ $\left.{ }^{\circ} 2 \mathrm{Th}.\right]$ & Height [cts] & FWHM [ $\left.{ }^{\circ} 2 \mathrm{Th}.\right]$ & $\mathrm{d}$-spacing $[\AA]$ & Rel. Int. [\%] \\
\hline 7.2627 & 137.20 & 0.0472 & 5.61092 & 1.26 \\
\hline 8.9857 & 258.78 & 0.3149 & 4.53663 & 2.37 \\
\hline 10.4520 & 368.48 & 0.1574 & 3.90160 & 3.38 \\
\hline 12.1995 & 10898.34 & 0.0630 & 3.34440 & 100.00 \\
\hline 12.9837 & 1637.99 & 0.0630 & 3.14319 & 15.03 \\
\hline 14.0871 & 1020.70 & 0.0945 & 2.89808 & 9.37 \\
\hline 14.8936 & 1135.16 & 0.1889 & 2.74197 & 10.42 \\
\hline 16.2422 & 592.95 & 0.1889 & 2.51565 & 5.44 \\
\hline 17.6866 & 1273.04 & 0.1260 & 2.31164 & 11.68 \\
\hline 19.1980 & 806.22 & 0.1889 & 2.13117 & 7.40 \\
\hline 20.1282 & 1320.46 & 0.3149 & 2.03362 & 12.12 \\
\hline 21.1090 & 1836.65 & 0.1344 & 1.93622 & 16.85 \\
\hline 21.2307 & 1597.75 & 0.0768 & 1.93689 & 14.66 \\
\hline 22.8250 & 569.59 & 0.2304 & 1.79238 & 5.23 \\
\hline 24.3763 & 1396.86 & 0.3456 & 1.67988 & 12.82 \\
\hline 25.0592 & 1063.39 & 0.3072 & 1.63480 & 9.76 \\
\hline 26.0774 & 827.39 & 0.3840 & 1.57201 & 7.59 \\
\hline 27.3126 & 411.05 & 0.4608 & 1.50217 & 3.77 \\
\hline 30.0432 & 357.54 & 0.3840 & 1.36837 & 3.28 \\
\hline 31.2868 & 259.93 & 0.9216 & 1.31526 & 2.39 \\
\hline 33.5645 & 780.09 & 0.0768 & 1.22832 & 7.16 \\
\hline 35.7889 & 759.42 & 0.3072 & 1.15425 & 6.97 \\
\hline 37.0546 & 369.46 & 0.4608 & 1.11614 & 3.39 \\
\hline
\end{tabular}




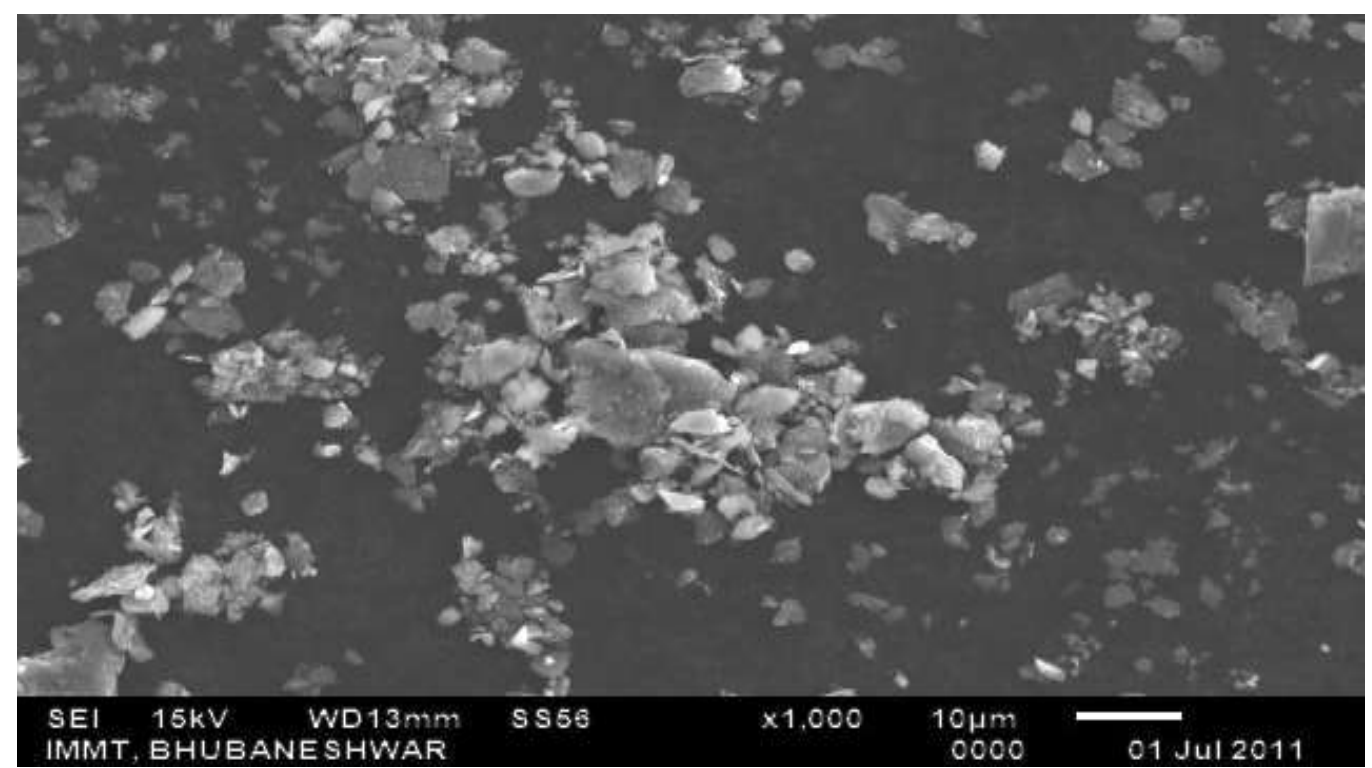

Figure 2: Scanning electron micrograph of SPL carbon powder.

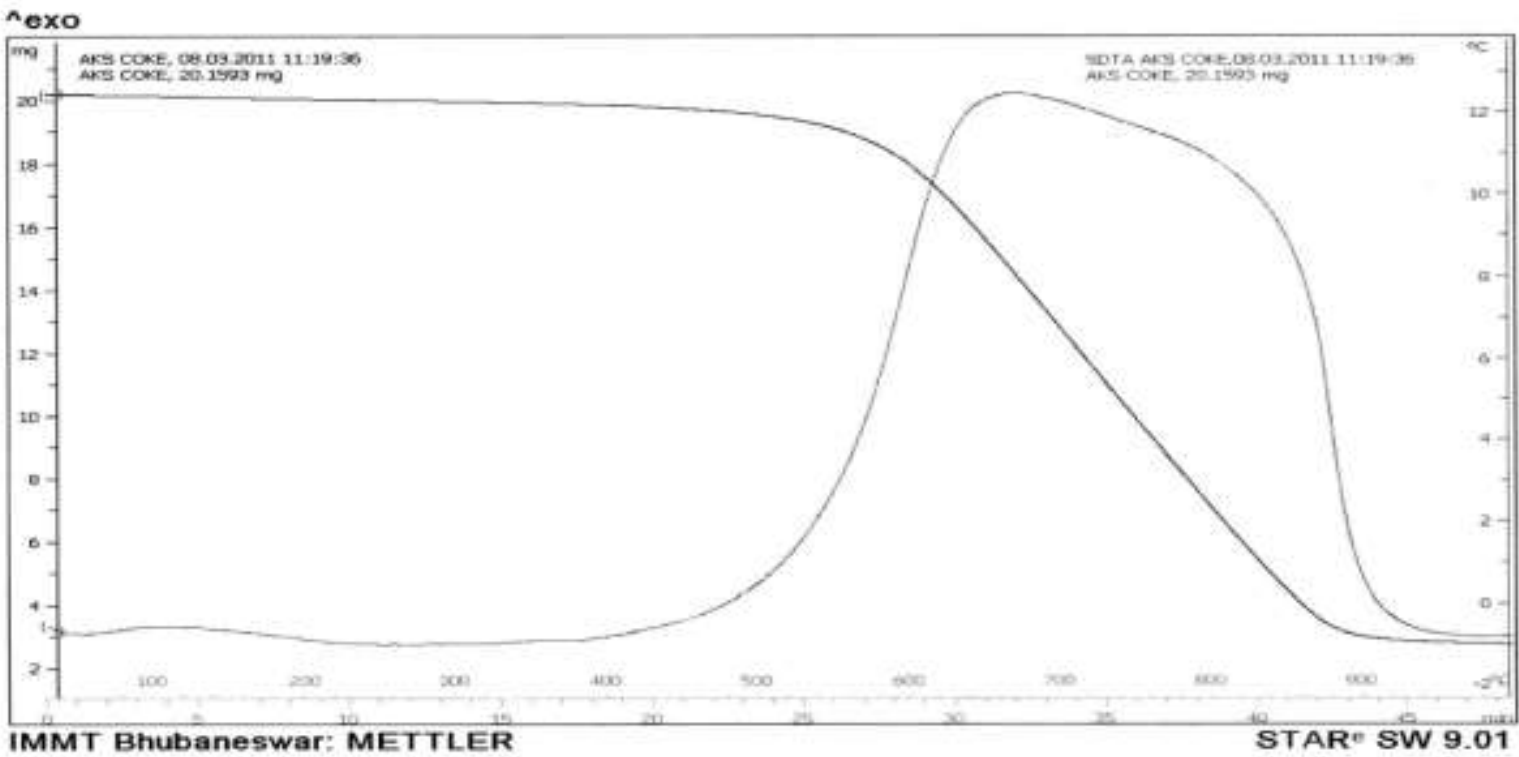

Figure 3: Differential thermal analysis of SPL carbon powder (Reference: graphite)

Table 4 : Properties of cured tap hole clay (Composition -1)

\begin{tabular}{|c|c|c|c|c|c|}
\hline Ingredients & $\%$ & Apparent & Bulk & Permanent & Cold \\
\hline & & porosity & density & linear & crushing \\
\hline & & & & shrinkage & strength \\
\hline Alumina & 28.35 & & & & \\
\hline Silica & 4.51 & & & & \\
\hline Silicon carbide & 13.5 & & & & \\
\hline Titania & 1.38 & & & & \\
\hline $\mathrm{Fe}_{2} \mathrm{O}_{3}$ & 1.42 & & & & \\
\hline Carbon from SPL & 23.86 & $27.65 \%$ & $1.38 \mathrm{gm} / \mathrm{cc}$ & $2.39 \%$ & $161 \mathrm{~kg} / \mathrm{cm}^{2}$ \\
\hline Liquid resin & 16 & & & & \\
\hline LOI (Solids) & 1.24 & & & & \\
\hline Moisture & 0.52 & & & & \\
\hline Solid resin & Nil & & & & \\
\hline
\end{tabular}


Table 5: Properties of cured tap hole clay (Composition -2)

\begin{tabular}{|c|c|c|c|c|c|}
\hline Ingredients & $\%$ & Apparent & Bulk & Permanent & Cold \\
\hline & & porosity & density & linear & crushing \\
\hline & & & & shrinkage & strength \\
\hline Alumina & 28.35 & & & & \\
\hline Silica & 4.51 & & & & \\
\hline Silicon carbide & Nil & & & & \\
\hline Titania & 1.38 & & & & \\
\hline $\mathrm{Fe}_{2} \mathrm{O}_{3}$ & 1.42 & & & & \\
\hline Carbon from SPL & 31.61 & $26.15 \%$ & $1.61 \mathrm{gm} / \mathrm{cc}$ & $2.41 \%$ & $153 \mathrm{~kg} / \mathrm{cm}^{2}$ \\
\hline Liquid resin & 20 & & & & \\
\hline LOI (Solids) & 1.24 & & & & \\
\hline Moisture & 0.76 & & & & \\
\hline Solid resin & Nil & & & & \\
\hline
\end{tabular}

Table-6: properties of some commercial tap hole compounds.

\begin{tabular}{lcccc|}
\hline $\begin{array}{l}\text { Company Apparent porosity } \\
\text { Name }\end{array}$ & Bulk density & $\begin{array}{c}\text { Permanent } \\
\text { Linear } \\
\text { Shrinkage }(\%)\end{array}$ & Cold crushing strength \\
\hline $\begin{array}{l}\text { Sino-global } \\
\text { sourcing \& } \\
\text { supply Ltd. }\end{array}$ & $25-35$ & $2.30 \mathrm{~g} / \mathrm{cc}$ & 1.0 & $61.5 \mathrm{~kg} / \mathrm{cm}^{2}$ \\
$\begin{array}{l}\text { Satguru } \\
\text { Refractories }\end{array}$ & $25-35$ & $2.8 \mathrm{~g} / \mathrm{cc}$ & -0.8 at $900^{0} \mathrm{C}$ & $75 \mathrm{~kg} / \mathrm{cm}^{2}$ \\
$\begin{array}{l}\text { India } \\
\text { ACC Refractories }\end{array}$ & $25-35$ & $1.54 \mathrm{~g} / \mathrm{cc}$ & -0.1 at $1400^{0} \mathrm{C}$ & \\
India. & & & +2.00 & $35 \mathrm{~kg} / \mathrm{cm}^{2}$ \\
\hline
\end{tabular}

\section{References}

[1] Grjotheim BJ (1980) Aluminum smelter technology. Aluminum Verlag GmbH. Dusseidorf, Germany .

[2] Jenkins DH (1993) Recovering aluminum and fluoride values from spent pot lining. U.S.Patent No. 5352419.

[3] Barnett RJ, Mezner MB (1998) Method of treating spent pot liner material from aluminum reduction cells. U.S. Patent No 2314123.

[4] Barnett RJ, Mezner MB(2001) Recovery of carbon, silica and alumina from spent pot liner. U.S. Patent No 6217836

[5] Barnett RJ, Mezner MB(2001) Recovering chloride and sulphate compounds from spent pot liner. U.S. Patent No 6231822.

[6] Report (2002), Aluminum smelting reprocessing of spent pot linings. Mat. World 10: 37

[7] Jenkins DH (1992) Recovering of aluminum and fluoride from spent pot lining. European Patent No WO/1992/012268.

[8] Mazumder B (2000) Aluminum waste cathodes can now be gainfully used as graphite. Min \& Met Rev 27: 35-41.

[9] Mazumder B (2002) A process for the preparation of fluffy variety of pyrogenic silica at a relatively lower temperature. Indian patent No. 006/NF.

[10] Mazumder B (2003) A process for the preparation of carbon refractories from spent cathodes of aluminum smelting plants. India Patent No 051/DEL.

[11] Mazumder B (2003) Chemical oxidation of cathode carbon blocks of aluminum Smelter plants for removal of contaminants and recovery of graphite value. J Sci \& Ind Res 62: 1181-1183.

[12] Mazumder B (2006) A process for making silicon carbide from spent pot liner of aluminum industries. European Patent No $06019439.6-1218$.

[13] Mazumder B, Ash B (2005) Utilization of spent pot liner (a waste material) of aluminum smelter plants. Proc Intl Seminar on Emerging Trends in Mineral Processing \& Extractive Metallurgy. 424-430.

[14] Mazumder B (2006) A process for making dry cell electrodes fro spent pot liners of aluminum industries. Indian Patent No 0395DEL

[15] Mazumder B (2008) A process for manufacture of mould coating fro SPL derived carbon powder. Indian Patent No 766/DEL.

[16] Mazumder B (2007) A process for preparation of pencil lead from spent pot liners of aluminum industries. US. Patent No $7,217,378 \mathrm{~B} 2$.

[17] Mazumder B, Devi SR (2008) Studies on removal of contaminants fro spent pot linings of aluminum smelter plant. Poll Res 27: 491-496.

[18] Mazumder B, Devi SR(2011) A process for making blast furnace tap hole compound from spent pot liners of aluminum smelter plant. Indian Patent applied.

[19] Dickie R C, Logan L L (1986). Spent pot liner in a cement kiln, Presented at the Portland Cement Association's Annual Meeting, Chicago, Illinois (USA). 